\title{
Positive p53 immunostaining and erythroid maturation in two cases of pure erythroid leukemia with extremely complex karyotypes
}

\author{
Masayuki Mita ${ }^{*}$, Mitsue Akino ${ }^{1}$, Yuya Shirato' ${ }^{1}$ Ken-ichi Nakamura' and Yoshihiro Nozawa²
}

*Correspondence: mmita2311@gmail.com

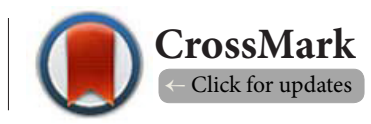

${ }^{1}$ Hematology and Oncology Center, Shirakawa Kosei General Hospital, Shirakawa, Japan.

${ }^{2}$ Diagnostic Pathology Center, Shirakawa Kosei General Hospital, Shirakawa, Japan.

\begin{abstract}
Pure erythroid leukemia (PEL) is characterized as a neoplastic erythroid hyperproliferation with maturation arrest, showing highly complex karyotypes, prominent clonal evolution, and a very aggressive clinical course. Here, we describe two cases of PEL that evolved from myelodysplastic syndrome (MDS), focusing on the immunophenotypic, cytogenetic, and molecular features of these cases. Case 1: A 77-yearold woman was diagnosed with PEL that evolved from MDS-refractory cytopenia with multilineage dysplasia. Her disease progressed rapidly despite 5 cycles of azacitidine treatment. The bone marrow (BM) aspirate revealed hypercellular marrow with 92.4\% erythroid cells, which expressed CD7 and CD36. Case 2: A 43-year-old woman had MDS-refractory anemia for more than 15 years. When her disease progressed rapidly, the BM aspirate revealed hypercellular marrow with $95.4 \%$ erythroid cells, which expressed CD235a. There were several significant findings in our cases. First, flow cytometric analysis of BM cells showed different stages of erythroid maturation. Second, cytogenetics revealed extremely complex karyotypes. Finally, immunohistochemistry showed strong nuclear staining for p53 in BM erythroid cells. We suggest that increased p53 protein expression is correlated with complex karyotypes and worse outcomes, indicating PEL with a high degree of malignant behavior.
\end{abstract}

Keywords: Pure erythroid leukemia, myelodysplastic syndrome, complex karyotype, double minute chromosome, p53

\section{Introduction}

Pure erythroid leukemia (PEL) is classified as "acute myeloid leukemia (AML), not otherwise specified (NOS)" subtype, and is now the only type of acute erythroid leukemia (AEL) according to the updated 2016 World Health Organization (WHO) classification of myeloid neoplasms and acute leukemia. PEL is defined as a neoplastic proliferation of immature cells that have an undifferentiated or proerythroblastic appearance representing $>80 \%$ immature erythroid precursors with $\geq 30 \%$ proerythroblasts in the bone marrow (BM) nucleated cells [1]. PEL is a rare leukemia, comprising less than $1 \%$ of all AML cases [2-4]. Approximately $39 \%$ of PEL cases evolved from myelodysplastic syndrome (MDS) [2]. Here, we describe two cases of PEL that evolved from MDS, noting the important clinical implications of their immunophenotypic, cytogenetic, and molecular features. Our cases showed different stages of erythroid maturation, extremely complex karyotypes, and increased p53 protein immunostaining in BM neoplastic cells. Strong p53 expression was correlated with complex karyotypes, leading to a highly aggressive clinical course and a dismal prognosis.

\section{Case presentation}

Case 1

A 77-year-old woman presented with shortness of breath in November 2013. Her initial blood count profile showed pancytopenia, with a hemoglobin level of $6.3 \mathrm{~g} / \mathrm{dL}$, white blood cell count of $3.5 \times 10^{9} / \mathrm{L}$, and platelet count of $69 \times 10^{9} / \mathrm{L}$. The BM aspirate revealed hypocellularity with trilineage myelodysplasia and $2.2 \%$ blasts (Table 1 ). She was diagnosed with MDS-refractory cytopenia with multilineage dysplasia (RCMD) and received azacitidine treatment. Six months after the initial diagnosis, by which time she had undergone 5 cycles 
of azacitidine treatment, she was admitted to our unit with high fever and malaise. The laboratory blood values were as follows: hemoglobin level of $6.7 \mathrm{~g} / \mathrm{dL}$, red blood cell count of $1.98 \times 10^{12} / \mathrm{L}$, white blood cell count of $1.4 \times 10^{9} / \mathrm{L}$, platelet count of $42 \times 10^{9} / \mathrm{L}$, reticulocyte count of $0.5 \%$, serum levels of lactate dehydrogenase of 4,324 IU/L (normal range, 119229), and C-reactive protein level of $9.47 \mathrm{mg} / \mathrm{dL}$. The Wilms tumor 1 (WT1) mRNA level increased aggressively from 3,600 to 37,000 copy/ $\mu \mathrm{g}$ RNA over a 3-month period (Figure 1). The BM aspirate was hypercellular with $92.4 \%$ erythroid precursors. The erythroid cells were predominantly proerythroblasts, and basophilic erythroblasts (Table 1). The neoplastic erythroid cells showed medium to large size with round nuclei, fine chromatin, prominent nucleoli, and basophilic cytoplasm with occasional cytoplasmic vacuoles (Figure 2-1a). Periodic acid-Schiff (PAS) staining revealed globular and block-like positivity in many erythroid cells (PAS staining positive rate, 81\%; Figure 2-1 b). Prussian blue staining showed a few sideroblasts, but no ringed sideroblasts were observed. The immunohistochemistry of erythroid cells in the BM clot section revealed strong nuclear staining of the $\mathrm{p} 53$ protein (Figure 2-1d). Flow cytometry of the BM cells showed positive expression of CD7 and CD36, but was negative for CD235a (Glycophorin A), CD3, CD41, CD56, CD71, CD117, and HLA-DR. Cytogenetic evaluation of BM cells was performed on 20 metaphases and detected a complex karyotype with 18 hyperdiploid (range,

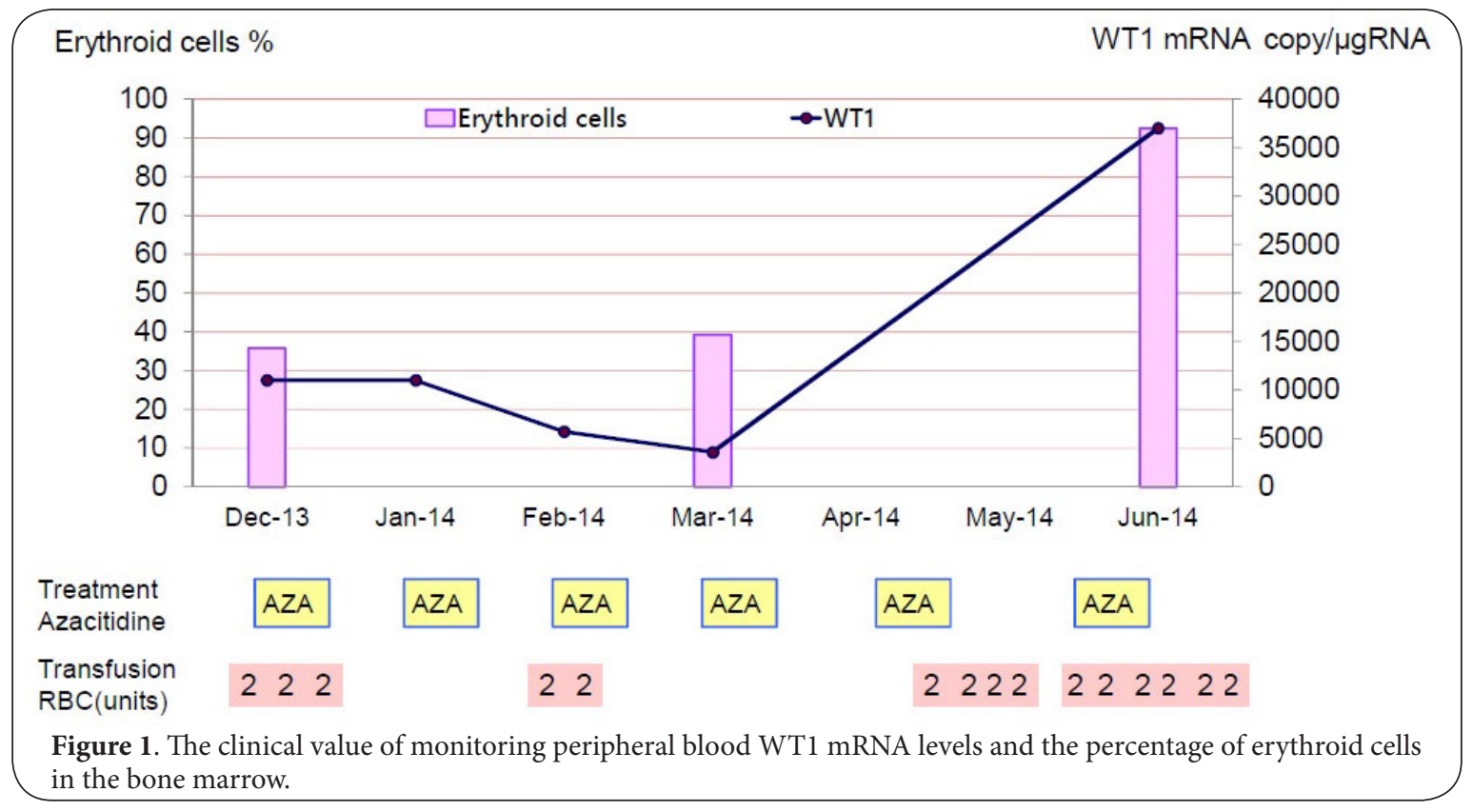

Table 1. Bone marrow aspirates at the diagnosis of myelodysplastic syndrome and the transformation to pure erythroid leukemia.

\begin{tabular}{lllll}
\hline & \multicolumn{3}{c}{ Case 1 } & Case 2 \\
\cline { 2 - 5 } & $\begin{array}{l}\text { Diagnosis } \\
\text { of MDS }\end{array}$ & $\begin{array}{l}\text { Transformation } \\
\text { to PEL }\end{array}$ & $\begin{array}{l}\text { Diagnosis } \\
\text { of MDS }\end{array}$ & $\begin{array}{l}\text { Transformation } \\
\text { to PEL }\end{array}$ \\
\hline $\begin{array}{l}\text { Nucleated cells } \times 104 / \mu \mathrm{L} \\
\text { Megakaryocytes / } \mu \mathrm{L}\end{array}$ & 1.6 & 5.3 & 11.9 & 11.4 \\
Blasts \% & 0 & 156 & 78.5 & 116 \\
Granulocytes \% & 2.2 & 2.4 & 1.6 & 0.8 \\
Monocytes \% & 37.4 & 4.0 & 56.4 & 2.0 \\
Lymphocytes \% & 4.8 & 0.0 & 1.2 & 0.0 \\
Erythroid cells \% & 15.6 & 1.2 & 6.2 & 1.8 \\
proerythroblasts \% & 35.8 & 92.4 & 33.6 & 95.4 \\
baso erythroblasts \% & 0 & 70.8 & 0.6 & 51.2 \\
poly erythroblasts \% & 22.4 & 17.0 & 1.4 & 6.0 \\
ortho erythroblasts \% & 7.4 & 4.4 & 29.8 & 24.8 \\
M:E ratio & 1.04 & 0.2 & 1.8 & 13.4 \\
\hline
\end{tabular}




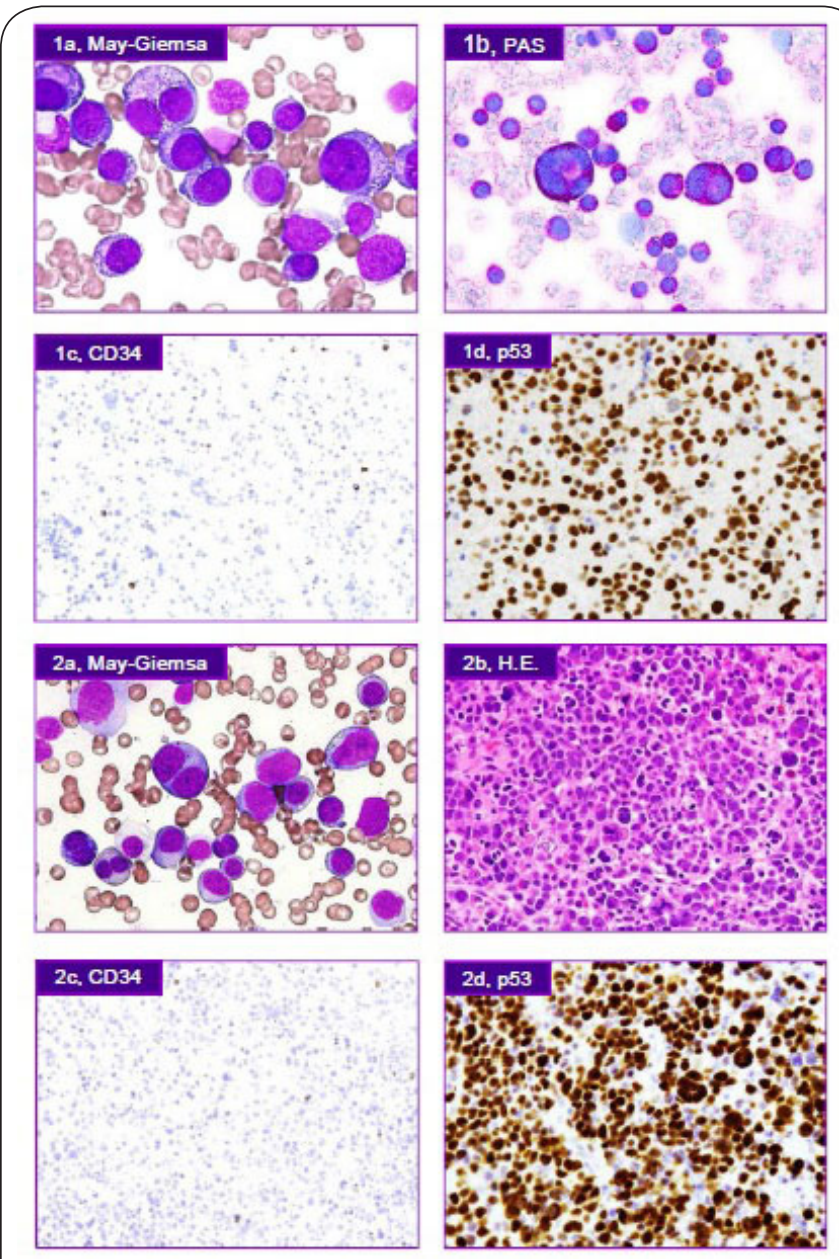

Figure 2. Morphological and immunohistochemical findings in pure erythroid leukemia.

Case 1: 1a, 1b, 1c, 1d. Case 2: 2a, 2b, 2c, 2d.

1a, 2a) Bone marrow aspirate smear showing marked dyserythropoiesis, including multinucleated erythroid precursors with cytoplasmic vacuolization $(\times 600)$. 1b) Periodic acid-Schiff staining showing positive granules in the cytoplasm of erythroid precursors $(\times 600) .2 b)$ Bone marrow clot section showing hypercellularity with increased erythroid precursors $(\times 200)$. 1c, 2 c) The erythroid precursors are CD34 negative; only rare CD34 myeloblasts are highlighted $(\times 100)$. 1d, 2d) The erythroid precursor cell nuclei showing positive expression of $\mathrm{p} 53$ protein $(\times 200)$.

52 to 57 chromosomes) and 2 hypertetraploid (range, 100 to 101 chromosomes) metaphases and an overall karyotype of double minute chromosomes (dmins) (Table 2, Figure 3). Despite further azacitidine treatment, the disease developed and progressed. She died of pneumonia 6 weeks after being diagnosed with PEL.

\section{Case 2}

A 43-year-old woman had MDS-refractory anemia for over 15 years. During the course of her disease, she was treated with oral methenolone acetate with no red blood cell transfusion requirement. In February 2013, her health rapidly worsened and she developed systemic signs of anemia. One month later, she was admitted to our unit because of genital bleeding, high fever, and shortness of breath. The laboratory blood values were as follows: hemoglobin level of $7.8 \mathrm{~g} / \mathrm{dL}$, red blood cell count of $2.46 \times 10^{12} / \mathrm{L}$, white blood cell count of $1.0 \times 10^{9} / \mathrm{L}$, platelet count of $5 \times 10^{9} / \mathrm{L}$, reticulocyte count of $0.6 \%$, serum levels of lactate dehydrogenase of 1,749 IU/L (normal range, 119-229), C-reactive protein level of $2.36 \mathrm{mg} / \mathrm{dL}$, and WT1 mRNA of less than $50 \mathrm{copy} / \mu \mathrm{g}$ RNA. The BM aspirate was hypercellular with $95.4 \%$ erythroid cells. Examination of the proliferated cells showed that medium sized undifferentiated erythroid cells or proerythroblasts comprised $51.2 \%$ of all BM nucleated cells (Table 1, Figure 2-2a). The erythroid cells in this case had a more differentiated form than did those in Case 1. PAS staining revealed positivity in many erythroid cells (PAS staining positive rate, $68 \%$ ). The immunohistochemistry of immature cells in the BM clot section revealed strong nuclear staining of the p53 protein (Figure 2-2d). The immunophenotypic analysis by flow cytometry showed that BM cells expressed CD235a, but were negative for CD3, CD7, CD41, CD56, CD71, CD117, and HLA-DR. Cytogenetic analysis of BM cells revealed complex karyotype abnormalities in all of the 20 metaphases with 18 hypertriploid or hypotetraploid karyotype (range, 78 to 82 chromosomes) (Table 2). Although azacitidine treatment was started, her condition worsened rapidly. She died of gastrointestinal bleeding 6 weeks after being diagnosed with PEL.

\section{Discussion}

In the updated 2016 WHO classification of myeloid neoplasms and acute leukemia, the AEL-erythroid/myeloid type subcategory has been removed from the AML category. As a result, PEL is now the only type of AEL. This change was based on the close biologic relationship of the AEL-erythroid/myeloid type to MDS in terms of its clinical presentation, morphologic features, and genetic abnormalities [1]. PEL is very rare form of leukemia, and some cases of PEL occur as a disease progression stage that has evolved from MDS [2-4]. Morphologic, immunophenotypic, cytogenetic, and molecular analysis are valuable for confirming the diagnosis of PEL. There were several significant findings in our cases. First, in flow cytometric analysis, the erythroid lineages of the two cases showed different immunophenotypic patterns. Second, cytogenetic analysis revealed extremely complex karyotypes, and dmins were found in Case 1. Finally, immunohistochemistry showed strong nuclear staining for p53 in BM cells.

Early erythroid cells were identified at three differentiation stages by flow cytometry. During the first stage, erythroid differentiation is characterized by expression of CD36, CD105, CD173, and CD238. At this stage, CD71-positive cells consist of both erythroid cells and myeloid cells. With ongoing differentiation, at the second stage, CD36, CD71, CD105, CD117, CD173, and CD238 can be observed, whereas CD45 
Mita et al. Hematology and Leukemia 2016,

http://www.hoajonline.com/journals/pdf/2052-434X-4-3.pdf

Table 2. Cytogenetic analysis of bone marrow cells.

\begin{tabular}{|c|c|}
\hline Case 1 & At the diagnosis of MDS-RCMD \\
\hline & $\begin{array}{l}46, \mathrm{XX}[10] \\
47, \mathrm{XX},-5,-7,+20, \operatorname{add}(20)(\mathrm{q} 11.2) \times 2, \operatorname{add}(22)(\mathrm{q} 11.2),+2 \operatorname{mar}[2] \\
48, \mathrm{XX},-5,-7,+20, \operatorname{add}(20)(\mathrm{q} 11.2) \times 2, \operatorname{add}(22)(\mathrm{q} 11.2),+3 \operatorname{mar}[8]\end{array}$ \\
\hline & At the transformation to PEL \\
\hline & $\begin{array}{l}\text { The following example chromosome is representative of the karyotype: } \\
55, \mathrm{XX},+2,+\operatorname{add}(2)(\mathrm{q} 21),+6, \operatorname{add}(7)(\mathrm{p} 22),+12,-13, \operatorname{add}(14)(\mathrm{p} 11.2),+15,+16,+17,+19,+21, \operatorname{add}(22)(\mathrm{p} 11.2),+ \text { mar,dmin } \\
54, \mathrm{XX},+\mathrm{X},+6,-7, \operatorname{add}(7)(\mathrm{p} 22),+8, \operatorname{add}(10)(\mathrm{q} 22),+12 \text {,add }(14)(\mathrm{p} 11.2),+15,+16,+17,+19, \operatorname{add}(22) \mathrm{p} 11.2),+ \text { mar,dmin } \\
54, \mathrm{XX},+2,-5,+6, \operatorname{add}(7)(\mathrm{p} 22),+8,-9,+12,-13, \operatorname{add}(14)(\mathrm{p} 11.2),+15,+19,+21, \operatorname{add}(22)(\mathrm{p} 11.2),+4 \mathrm{mar}, \mathrm{dmin} \\
100, \mathrm{XXXX}, \operatorname{add}(7)(\mathrm{p} 22) \mathrm{X} 2,+8,+8,-9,-9,-10,-11,+12,-13,-13,-13, \operatorname{add}(14)(\mathrm{p} 11.2),+15,+\operatorname{add}(15) \\
(\mathrm{p} 11.2),+16,+16,+17,+17,-18,+19,+19,+19,+20,+21+21,-22,-22, \operatorname{add}(22)(\mathrm{p} 11.2) \times 2,+3 \mathrm{mar}, \mathrm{dmin}\end{array}$ \\
\hline \multirow[t]{4}{*}{ Case 2} & At the diagnosis MDS-RA \\
\hline & $46, \mathrm{XX}[20]$ \\
\hline & At the transformation to PEL \\
\hline & $\begin{array}{l}\text { The following example chromosome is representative of the karyotype: } \\
45, \mathrm{XX}, \mathrm{t}(1 ; 9)(\mathrm{p} 10 ; \mathrm{p} 10), \operatorname{add}(6)(\mathrm{p} 21.3), \operatorname{add}(9)(\mathrm{p} 22),-10, \operatorname{add}(19)(\mathrm{p} 13.3), \operatorname{add}(21)(\mathrm{p} 11.2)[2] \\
81, \mathrm{XXX},-\mathrm{X},-3,-4,-9,-10,-10,-11,-12, \operatorname{add}(12)(\mathrm{p} 11.2),-14,-16,-18, \operatorname{add}(19)(\mathrm{p} 13.3) \times 2,-20, \operatorname{add}(21)(\mathrm{p} 11.2) \times 2,+\operatorname{mar}[2]\end{array}$ \\
\hline
\end{tabular}

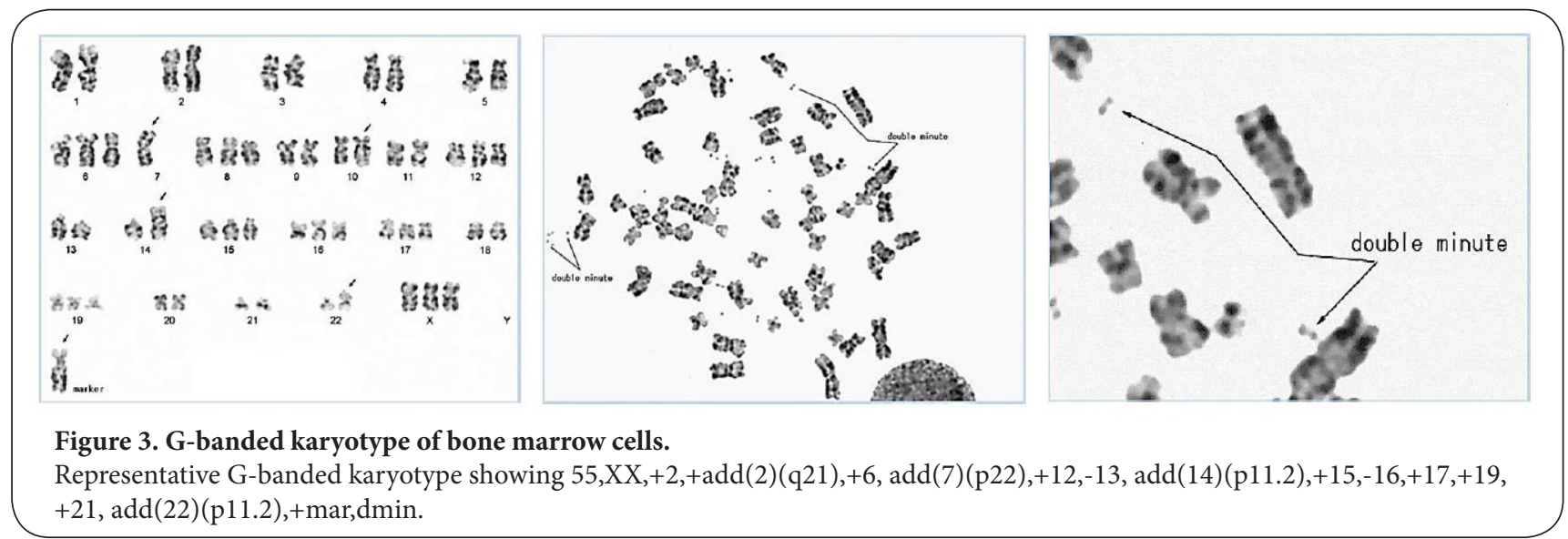

expression is diminished and HLA-DR is no longer detectable. The third stage is defined by the appearance of CD235a and the disappearance of CD117 [5,6]. In Case 1, neoplastic cells were positive for CD36, but negative for CD235a, exhibiting the early stage after commitment to the erythroid lineage. On the other hand, neoplastic cells in Case 2 were positive for CD235a, indicating a more differentiated form than was observed in Case 1. In addition, neoplastic cells were positive for CD7 in Case 1. Although CD7 is not usually expressed in erythroid lineages, the expression of $C D 7$ has been reported in $12-42 \%$ of AML cases [7]. Abnormal erythroid maturation may be due to changes in the intensity of antigen expression and maturation arrest, as well as gains and losses or modifications of antigen expression. Immunophenotypic analysis revealed that neoplastic cells in Case 1 were early erythroid progenitor cells, while those in Case 2 were later erythroid cells. Morphologically, the percentage of undifferentiated erythroid cells or proerythroblasts in Case 1 was higher than that in Case 2. Based on these results, it appeared that the rapidly aggressive clinical course was not related to the erythroid differentiation stage of the neoplastic cells.
Cytogenetically, no specific chromosome abnormality has been described in PEL, but complex karyotypes with multiple structural abnormalities are common, especially with $-5 /$ del $(5 q)$, $-7 /$ del(7q), and trisomy 8 [2,4]. Chromosomal abnormalities have been found in approximately $55 \%$ of adult AML cases. Additionally, complex karyotypes with $\geq 3$ aberrations account for $10-19 \%$ of adult AML cases [8]. During the progression of MDS to AML, cytogenetically complex karyotypes are often acquired, especially in cases of PEL $[2,4]$. Interestingly, dmins were only detected in Case 1, and were not observed in PEL previously. Dmins are small, paired chromatin bodies that represent a form of extrachromosomal gene amplification. They are frequently found in various solid tumors, but appear in less than $1 \%$ of AML and MDS. They are often associated with complex karyotypes, and are generally associated with a poor prognosis. Dmins in myeloid neoplasms commonly harbor MYC or MLL gene amplification and manifest as micronuclei within leukemic cells $[9,10]$.

Although DNA sequencing was not performed in our cases, immunohistochemistry showed strong nuclear staining of the p53 protein in the BM erythroid cells. p53 is a tumor 
Mita et al. Hematology and Leukemia 2016,

suppressor protein that is encoded by the TP53 gene and regulates the cell cycle in response to cellular stress, leading to DNA damage. TP53 mutations are detected in $5-10 \%$ of MDS and AML cases, and $53-72 \%$ of AML that have complex karyotypes [11-13]. In case of del(5q) MDS, a strong accumulation of p53 protein was found in erythroid progenitor cells; in contrast, myeloid or megakaryocyte lineage cells did not have increased p53 expression. Therefore, the p53 pathway may play an important role in the erythroid lineage, improving the efficiency of erythropoiesis and preventing malignant transformation $[14,15]$. Significantly, immunohistochemical analysis of p53 expression is a clinically useful tool that does not require expensive gene sequencing techniques and is readily available for routine clinical use $[12,14,15]$. In our cases, strong positive immunostaining for $\mathrm{p} 53$ might have led to resistance to treatment and a short survival time. Taken together, it appears that TP53 mutations in MDS and AML are correlated with complex karyotypes and dismal outcomes.

\section{Conclusions}

In the updated 2016 WHO classification, PEL is now the only type of AEL. The reported cases showed increased $\mathrm{p} 53$ protein expression and illustrate the potential importance of this increased expression to future disease progression and management. Our cases suggest that morphologic, immunophenotypic, cytogenetic, and molecular evaluations of leukemic cells are needed to improve the current understanding of the pathogenesis of PEL. Such evaluations ultimately have clinical importance because leukemic cells play important roles in disease development and/or progression.

\section{Competing interests}

The authors declare that they have no competing interests.

Authors' contributions

\begin{tabular}{|l|c|c|c|c|c|}
\hline Authors' contributions & MM & MA & YS & KN & YN \\
\hline Research concept and design & $\checkmark$ & $\checkmark$ & $\checkmark$ & $\checkmark$ & $\checkmark$ \\
\hline Collection and/or assembly of data & $\checkmark$ & $\checkmark$ & $\checkmark$ & $\checkmark$ & $\checkmark$ \\
\hline Data analysis and interpretation & $\checkmark$ & $\checkmark$ & $\checkmark$ & $\checkmark$ & $\checkmark$ \\
\hline Writing the article & $\checkmark$ & $\checkmark$ & $\checkmark$ & $\checkmark$ & $\checkmark$ \\
\hline Critical revision of the article & $\checkmark$ & $\checkmark$ & $\checkmark$ & $\checkmark$ & $\checkmark$ \\
\hline Final approval of article & $\checkmark$ & $\checkmark$ & $\checkmark$ & $\checkmark$ & $\checkmark$ \\
\hline Statistical analysis & $\checkmark$ & $\checkmark$ & $\checkmark$ & $\checkmark$ & $\checkmark$ \\
\hline
\end{tabular}

Publication history

EIC: Evangelos Terpos, University of Athens School of Medicine, Greece. Received: 29-Sep-2016 Final Revised: 08-Nov-2016

Accepted: 02-Dec-2016 Published: 13-Dec-2016

\section{References}

1. Arber DA, Orazi A, Hasserjian R, Thiele J, Borowitz MJ, Le Beau MM, Bloomfield CD, Cazzola M and Vardiman JW. The 2016 revision to the World Health Organization classification of myeloid neoplasms and acute leukemia. Blood. 2016; 127:2391-405. | Article | PubMed

2. Liu W, Hasserjian RP, Hu Y, Zhang L, Miranda RN, Medeiros LJ and Wang
SA. Pure erythroid leukemia: a reassessment of the entity using the 2008 World Health Organization classification. Mod Pathol. 2011; 24:375-83. | Article | PubMed

3. Santos FP, Faderl S, Garcia-Manero G, Koller C, Beran M, O'Brien S, Pierce S, Freireich EJ, Huang X, Borthakur G, Bueso-Ramos C, de Lima M, Keating $\mathrm{M}$, Cortes J, Kantarjian $\mathrm{H}$ and Ravandi F. Adult acute erythroleukemia: an analysis of 91 patients treated at a single institution. Leukemia. 2009; 23:2275-80. | Article | PubMed Abstract | PubMed FullText

4. Bacher U, Haferlach C, Alpermann T, Kern W, Schnittger S and Haferlach T. Comparison of genetic and clinical aspects in patients with acute myeloid leukemia and myelodysplastic syndromes all with more than $50 \%$ of bone marrow erythropoietic cells. Haematologica. 2011; 96:1284-92. | Article | PubMed Abstract | PubMed FullText

5. Machherndl-Spandl S, Suessner S, Danzer M, Proell J, Gabriel C, Lauf J, Sylie R, Klein HU, Bene MC, Weltermann A and Bettelheim P. Molecular pathways of early CD105-positive erythroid cells as compared with CD34-positive common precursor cells by flow cytometric cell-sorting and gene expression profiling. Blood Cancer J. 2013; 3:e100. | Article PubMed Abstract I PubMed FullText

6. Mori Y, Chen JY, Pluvinage JV, Seita J and Weissman IL. Prospective isolation of human erythroid lineage-committed progenitors. Proc Natl Acad Sci U S A. 2015; 112:9638-43. | Article | PubMed Abstract | PubMed FullText

7. Ortolani C. Antigens 'CD7 antigen'. In Flow cytometry of hematological malignancies. Wiley-Blackwell, UK; 2011:22-3.

8. Stolzel F, Mohr B, Kramer M, Oelschlagel U, Bochtler T, Berdel WE, Kaufmann M, Baldus CD, Schafer-Eckart K, Stuhlmann R, Einsele H, Krause SW, Serve $\mathrm{H}$, Hanel $\mathrm{M}$ and Herbst $\mathrm{R}$ et al. Karyotype complexity and prognosis in acute myeloid leukemia. Blood Cancer J. 2016; 6:e386. I Article | PubMed Abstract | PubMed FullText

9. Thomas L, Stamberg J, Gojo I, Ning Y and Rapoport AP. Double minute chromosomes in monoblastic (M5) and myeloblastic (M2) acute myeloid leukemia: two case reports and a review of literature. Am J Hematol. 2004; 77:55-61. | Article | PubMed

10. Huh YO, Tang G, Talwalkar SS, Khoury JD, Ohanian M, Bueso-Ramos $\mathrm{CE}$ and Abruzzo LV. Double minute chromosomes in acute myeloid leukemia, myelodysplastic syndromes, and chronic myelomonocytic leukemia are associated with micronuclei, MYC or MLL amplification, and complex karyotype. Cancer Genet. 2016; 209:313-20. | Article | PubMed

11. Rucker FG, Schlenk RF, Bullinger L, Kayser S, Teleanu V, Kett H, Habdank M, Kugler CM, Holzmann K, Gaidzik VI, Paschka P, Held G, von LilienfeldToal M, Lubbert M, Frohling S, Zenz T, Krauter J, Schlegelberger B, Ganser A, Lichter P, Dohner K and Dohner H. TP53 alterations in acute myeloid leukemia with complex karyotype correlate with specific copy number alterations, monosomal karyotype, and dismal outcome. Blood. 2012; 119:2114-21. | Article | PubMed

12. Kulasekararaj AG, Smith AE, Mian SA, Mohamedali AM, Krishnamurthy P, Lea NC, Gaken J, Pennaneach C, Ireland R, Czepulkowski B, Pomplun S, Marsh JC and Mufti GJ. TP53 mutations in myelodysplastic syndrome are strongly correlated with aberrations of chromosome 5 , and correlate with adverse prognosis. Br J Haematol. 2013; 160:660-72. | Article | PubMed

13. Hou HA, Chou WC, Kuo YY, Liu CY, Lin LI, Tseng MH, Chiang YC, Liu MC, Liu CW, Tang JL, Yao M, Li CC, Huang SY, Ko BS, Hsu SC, Chen CY, Lin CT, Wu SJ, Tsay W, Chen YC and Tien HF. TP53 mutations in de novo acute myeloid leukemia patients: longitudinal follow-ups show the mutation is stable during disease evolution. Blood Cancer J. 2015; 5:e331. | Article | PubMed Abstract | PubMed FullText

14. Saft L, Karimi M, Ghaderi M, Matolcsy A, Mufti GJ, Kulasekararaj A, Gohring G, Giagounidis A, Selleslag D, Muus P, Sanz G, Mittelman M, Bowen D, Porwit A, Fu T, Backstrom J, Fenaux P, MacBeth KJ and Hellstrom-Lindberg E. p53 protein expression independently predicts outcome in patients with lower-risk myelodysplastic syndromes with 
Mita et al. Hematology and Leukemia 2016,

http://www.hoajonline.com/journals/pdf/2052-434X-4-3.pdf

del(5q). Haematologica. 2014; 99:1041-9. | Article | PubMed Abstract | PubMed FullText

15. Dutt S, Narla A, Lin K, Mullally A, Abayasekara N, Megerdichian C, Wilson FH, Currie T, Khanna-Gupta A, Berliner N, Kutok JL and Ebert BL. Haploinsufficiency for ribosomal protein genes causes selective activation of p53 in human erythroid progenitor cells. Blood. 2011; 117:2567-76. | Article | PubMed Abstract | PubMed FullText

\section{Citation:}

Mita M, Akino M, Shirato Y, Nakamura K-i and Nozawa Y. Positive p53 immunostaining and erythroid maturation in two cases of pure erythroid leukemia with extremely complex karyotypes. Hematol Leuk. 2016; 4:3. http://dx.doi.org/10.7243/2052-434X-4-3 